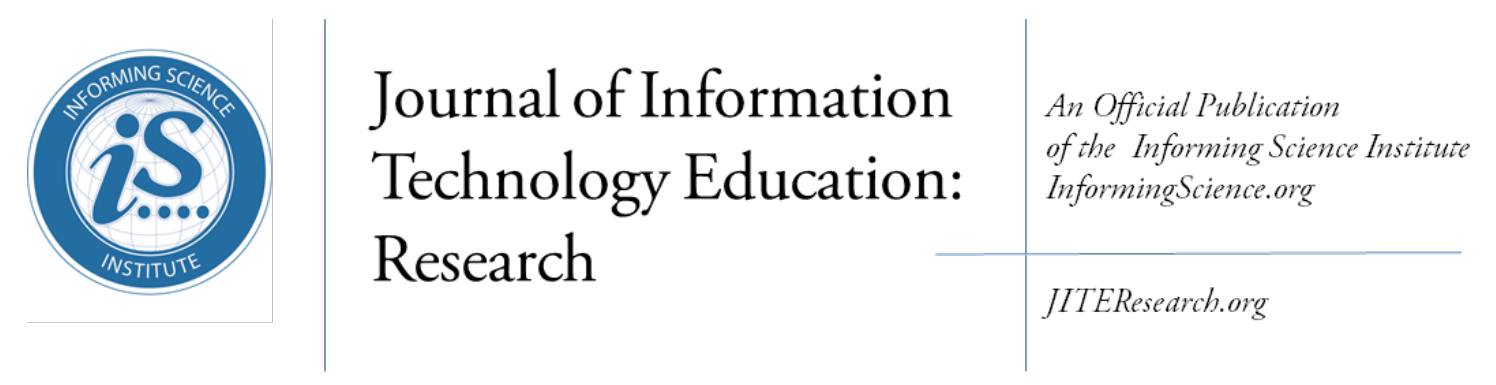

Volume 16, 2017

\title{
TEACHERS' READINESS TO IMPLEMENT DIGITAL CURRICULUM IN KUWAITI SCHOOLS
}

Hamed Al-Awidi*
Fayiz Aldhafeeri
* Corresponding author

Kuwait University, Kuwait, Kuwait

Kuwait University, Kuwait, Kuwait hamedalawidi@gmail.com

professor.fayiz@gmail.com

\section{ABstract}

Aim/Purpose

The goal of this study was to investigate how Kuwaiti teachers perceive their own readiness to implement digital curriculum in public schools, and the factors that affect Kuwaiti teachers' readiness to implement digital curriculum from their perspectives.

Background

In order to shift from the traditional instructional materials to digital and more innovative resources, teachers have to be prepared for the transformational curriculum. Teachers need to acquire all the technical and pedagogical skills that enable them to integrate digital technology effectively and efficiently into the school curriculum.

Methodology

Using a mixed-method research methodology, a random sample of 532 teachers participated in an online survey to determine the level of their readiness. In addition, semi-structured interviews were conducted with a sub sample of the participants (21) to explore the factors that affect their readiness. The researchers developed and implemented a technology readiness survey in two domains (technical and pedagogical).

Contribution The study demonstrated that Kuwaiti teachers were not highly ready to implement the digital curriculum, and some issues should be considered to ensure the digital curriculum is effectively implemented.

Findings

Teachers are moderately ready for implementation of the digital curriculum in both components of readiness (technical and pedagogical). Teachers identified some factors that that hinder their readiness. These factors are related to time constraints, knowledge and skills, infrastructure, and technical support.

Accepted by Editor Jo Coldwell-Neilson | Received: September 4, 2016| Revised: November 27, December 18, 2016; February 14, March 2, 2017 | Accepted: March 17, 2017.

Cite as: Al-Awidi, H., \& Aldhafeeri, F. (2017). Teachers' readiness to implement digital curriculum in Kuwaiti schools. Journal of Information Technology Education: Research, 16, 105-126. Retrieved from http://www.informingscience.org/Publications/3685

(CC BY-NC 4.0) This article is licensed to you under a Creative Commons Attribution-NonCommercial 4.0 International License. When you copy and redistribute this paper in full or in part, you need to provide proper attribution to it to ensure that others can later locate this work (and to ensure that others do not accuse you of plagiarism). You may (and we encourage you to) adapt, remix, transform, and build upon the material for any non-commercial purposes. This license does not permit you to use this material for commercial purposes. 
Recommendations This paper will guide curriculum decision makers to find the best ways to for Practitioners help and support teachers to effectively implement the digital.

Future Research Follow up studies may examine the effectiveness of teacher education programs in preparing students teachers to implement the digital curriculum, and the role of education decision makers in facilitating the implementation of the digital curriculum.

Keywords digital curriculum, educational technology, Kuwait education, technology readiness

\section{INTRODUCTION}

In recent years, decision makers in the field of education in different countries, including the State of Kuwait, have been paying more attention to the integration of ICT into the curriculum and all other elements relevant to the whole process of teaching and learning. They have always payed attention to the issue of developing teachers' competencies to integrate technology into the curriculum and to enhance their abilities to create technology-based teaching and learning environments (Lim, Chai, \& Churchill, 2011). In order to shift from the traditional instructional materials to digital and more innovative resources, teachers have to be prepared for the transformational curriculum. To be ready for this shift, teachers need to have all the competencies that will help them adopt this change successfully. These competencies include skills and knowledge in the use of digital tools in all curriculum domains and making students' learning extend beyond the classroom (Bonanno, 2011).

Technology has great potential to enhance curriculum and teaching processes. However, teachers may not be ready to integrate technology and not have adequate knowledge and skills to utilize technology to support the curriculum. Researchers and the educational agencies in the last decade have focused on preparing teachers to integrate digital technology in instruction. The National Council for Accreditation of Teacher Education (NCATE) emphasized that teachers must take advantage of technology for instruction and be prepared to use technology effectively in the classroom (Afshari, Ghavifekr, Siraj, \& Jing, 2013). In order to be ready to integrate technology in the curriculum, teachers must be provided with a solid foundation of knowledge and skills in digital media and develop new understandings, new approaches, new roles, new forms of professional development, and new attitudes about technology integration (Ruggiero \& Mong, 2015; Sabzian \& Gilakjani, 2013). Teachers need to make a paradigm shift in their conception of curriculum and move from printed traditional curriculum to digital curriculum.

The successful implementation of digital technology into the curriculum relies heavily on teachers' readiness and willingness to adopt technology (Singh \& Chan, 2014; Summaka, Baglibel, \& Samancioglu, 2010). Teachers can integrate digital technology to supplement and support the curriculum, facilitate teachers' work, and encourage student-centered learning (Ertmer, Ottenbreit-Leftwich, Sadik, Sendurur, \& Sendurur, 2012). To meet the new demands, teachers need to know more than core subjects. They need to acquire all the technical and pedagogical skills that enable them to integrate digital technology effectively and efficiently into the school curriculum.

The new national curriculum standards in the State of Kuwait emphasize that teachers should "employ teaching and learning methods that integrate innovative and research-proven teaching strategies, modern learning technologies and utilize real-world resources and contexts." (Ministry of Education, 2015, p.108). The Ministry of Education (MoE) has launched many strategic projects to transform curriculum from a printed version to a digital version. The projects emphasized the new role of the teacher to be a leader and guide the educational process to meet the new demands and the new visions (Mohammed, 2014).

The MoE in Kuwait has realized the importance of teachers' technological readiness in order to be able to integrate technology in their teaching. The $\mathrm{MoE}$ has provided ongoing training programs for 
teachers to enhance their skills to integrate technology in the curriculum (UNESCO, 2011). The $\mathrm{MoE}$ introduced policies to provide all schools with technological infrastructure and provide teachers with training programs to develop their capabilities in ICT (Al Sharija, 2012). All teachers in Kuwaiti schools must gain an International Computer Driving License (ICDL) (Al Sharija \& Qablan, 2012), to guarantee that they have the basic skills that will assist them to use the available ICT resources in their schools (Alharbi, 2012). Furthermore, the MoE offers incentives and rewards for teachers to foster the integration of ICT in the curriculum (Ministry of Education, 2003).

These recent efforts by the MoE in Kuwait and the high investment of technology in education raise many significant questions: Are teachers ready to shift from the printed curriculum to the digital curriculum, and what factors influence their ability to do so effectively? This paper investigates the technological and pedagogical readiness levels of Kuwaiti teachers to implement digital curriculum and explores the factors that may affect teachers' decisions to integrate technology into the curriculum. In fact, understanding the pedagogical and technological factors can help overcome the barriers to integrate technology in the classroom (Afshari et al., 2013).

\section{LITERATURE REVIEW}

Introducing digital technology to the classrooms has changed the ways in which teachers perceive education (Koo, 2008) and how they implement the curriculum (Sessoms, 2008). Teachers and students have new roles due to the shift from traditional teaching and learning methods to new methods that are based on technology. The greatest shift is in curriculum; moving toward integration of technology has shifted the focus from traditional curriculum to the digital curriculum (Moeller \& Reitzes, 2011). According to Abbey (2009), "the digital curriculum is to assure that there is a prevailing digital component to every important component of teaching and learning in a school" (p. 2). Digital curriculum is any digital content that takes many forms to support the delivery of the curriculum and facilitates the achievement of educational goals. It can be any digital media that is created in an open source format available and accessible for students at all time. Digital media can be defined as any form of information that is stored digitally and can be accessed through multiple sources including subscriptions, free online resources, and other digital devices. It includes text, graphics, audio, video, internet applications and other technologies that can be used to create and deliver digital curriculum (Tatnall, Kereteletswe, \& Visscher, 2011). Students can use additional digital media that are collected into a system to access and share learning materials (Martin, 2015).

\section{DIGITAL TECHNOLOGY AND CURRICULUM}

Digital technology allows students and teachers to interact with the curriculum through the use of a wide range of digital devices including desktop computers, laptops, digital cameras, mobile phones, and smartboards (Purcell, Buchanan, \& Friedrich, 2013). When these tools are integrated effectively into the curriculum and instruction, they enhance learning in influential ways. These tools can give students and teachers the opportunities to reach primary source learning materials, utilizing new methods to collect and record data, communicate, and share learning experiences with teachers; moreover, students can publish and present their knowledge (Eady \& Lockyer, 2013). Other electronic resources can support the digital curriculum, such as Twitter, Blogs, Wikis, and Youtube, and other applications can be used to engage and instruct and for assessing students' learning. Students and teachers are anticipated to be connected to these resources all the time while learning and to personalize their learning via the use of technology (Moeller \& Reitzes, 2011).

\section{TECHNOLOGY INTEGRATION AND CURRICULUM}

When the digital curriculum is implemented, it gives schools more flexibility in providing innovative teaching and learning activities based on technology. One of the options is blended learning which combines online learning with other means of instructional dissemination (Williamson \& Payton, 2009). Although students join a physical classroom in face-to-face learning, they can still participate 
Teachers' Readiness to Implement Digital Curriculum in Kuwaiti Schools

in a digital curriculum with self-paced learning whenever they need. Teachers may choose to allocate students in small groups where they use technology tools to manage their own learning (Moeller \& Reitzes, 2011).

The notion of technology integration does not mean the placement of technological tools in a classroom where the focus is on technology per se (Smaldino, Lowther, \& Russell, 2008), nor is it the use of technology to support traditional methods of teaching. It is rather the integration of technology to exceed the traditional teacher-centered approach where learners use the technology to learn 'with' and 'through' computers (Du Plessis \& Webb, 2012). Introducing technology in the classroom requires a paradigm shift in teaching and learning. Teachers are most affected by this change. Their readiness to meet the new demands for implementing curriculum will determine the success of this process. The teachers' responsibility in the process of technology integration in schools is vital, and any transition to digital curriculum should take into account teachers' readiness to integrate technology (Cuban, 2001). Teachers' readiness is one of the major influencing factors that may affect teachers' use of technology, and it has a significant positive direct effect on technology integration in education (Inan \& Lowther, 2009).

\section{COMPONENTS OF THE TEACHERS'READINESS}

Based on the above, technology readiness can be defined as a concept that describes people's tendency to use technologies for achieving goals (Parasuraman, 2000). Readiness has to do with teachers' awareness, knowledge of use, perceptions, and attitudes toward their capabilities and skills for technology integration as well as gaining experience in the use of educational technology (Msila, 2015).

Researchers have identified two components of technological readiness: technical and pedagogical readiness. These factors are considered crucial for the success of any technological innovation in teaching and learning $(\mathrm{Ng}, 2011)$. A comparative study of pedagogy and ICT use in schools in 22 different countries concluded that teachers' pedagogical and technical competence in the use of technology are significant predictors for technology adoption in teaching practice (Law \& Chow, 2008). These two components have been examined through the categories of knowledge, attitudes, skills, and habits (Bonanno, 2011; Eslaminejad, Massood, \& Ngah, 2010).

\section{Factors affect teachers' readiness to adopt technology}

Research on teachers' readiness to adopt technology in their teaching practices has evolved in the last few years along different dimensions ranging from schools readiness, to the availability of resources and teachers competence development (Bonanno, 2011). A review of the current literature suggests many factors that affect teachers' readiness to integrate technology. These factors include teachers' characteristics, contents knowledge, technological considerations, and organizational capability. Research highlighted a complex pattern of interrelated factors that are expected to be determinants of the successful integration of technology in education (Player-Koro, 2012). These factors may facilitate or hinder teachers' use of technology and appear from either the external environment or the personal characteristics of teachers. Balanskat, Blamire \& Kefalla (2007) mentioned other factors at the teacher-level, school-level, and system-level. Many researchers, such as Sherry and Gibson (2002), suggested that four factors should be taken into consideration when planning to introduce technology in schools. These are related to technological, individual, organizational, and institutional factors. Buabeng-Andoh (2012) added other factors that hinder teachers from the integration of technology in their classrooms, such as teacher technological skills; teacher confidence; pedagogical teacher training; insufficient access to ICT; structure of education systems; and restrictive curriculum.

Teacher-readiness to implement technology across grade levels was the focus of many researchers. The literature has revealed some controversy about the relationship between teachers' readiness to integrate technology and teaching levels. Secondary schools teachers "were somewhat more likely to report frequent student computer use during class (19 percent vs. 15 percent), even though they met with their classes on perhaps half the number of days as teachers who taught traditional 50-minute 
periods" (Becker \& Anderson, 2001, p. 3). A recent study conducted by Williams (2015) revealed differences in teachers attitudes toward computer technology integration attributed to the grade levels that they teach. The study found that elementary school teachers have more positive attitudes than high and middle school teachers. In their study, Barron, Kemker, Harmes, and Kalaydjian (2003) stated that elementary school teachers were twice as likely to integrate technology into their classrooms as secondary teachers were. Other studies (Russell, Bebell, \& O’Dwyer, 2004; Wozney, Venkatesh, \& Abrami, 2006) supported Barron et al.'s findings. Wozney et al's findings revealed that elementary teachers integrate computer technology in their instruction more frequently than secondary teachers do. Other studies have shown conflicting results. Badri, Al Rashedi, Yang, Mohaidat, and Al Hammadi (2014) found no relationship between teachers' technology-readiness and the grade levels they teach.

Research has repeatedly acknowledged a need to investigate differences among teachers in their readiness to integrate technology in different areas (Howard, Chan, \& Caputi, 2015). Each subject constitutes a body of knowledge, concepts, and skills, and teachers use different teaching and learning strategies. In mathematics, students do drills and practice activities, while social studies' students conduct daily research, and English students use computers for writing regularly (Zucker \& Hug, 2007). Each subject requires different kinds of digital application. Some technology tools and applications appear to match with specific subject areas: for example graphing software use in mathematics (Hennessy, Ruthven, \& Brindley, 2005), visualizations that can be used in teaching science (Webb \& Cox, 2004) and some language skills (Silvernail \& Gritter, 2007). Understanding of differences in technology integration among subject areas is essential if teachers are to appropriately and effectively integrate technology in their practice and achieve specific learning outcomes. Researchers investigated the differences of readiness to integrate technology among teachers who teach different subjects. Badri et al. (2014) conducted a study to explore teachers' readiness to integrate technology into education in Abu Dhabi in the United Arab Emirates. The study found no relationship between teachers' technology-readiness levels with either their subject or the grade levels they teach. This result is similar to the result of a previous study conducted by Summak et al. (2010), which found no significant differences among teachers in their technology readiness across the subject areas. In contrast, a study by Howard et al. (2015) revealed that teachers' readiness to integrate technology into instruction has significant associations with teachers' subject area.

Other factors that determine the successful use of technology in education is teaching experience. Findings of existing research (Bebell, Russell, \& O'Dwyer, 2004; Ertmer et al., 2012; Kalogiannakis, 2008) confirmed that there is a relationship between teachers' readiness to use technology and years of teaching experience. However, the literature reveals unclear and contradictory results. While some research (Baek, Jong, \& Kim, 2008; Singh \& Chan, 2014) reported that novice teachers implement technology in their instruction more than teachers with high experience do, other research showed the opposite and declared that experienced teachers implement technology more than beginner teachers do (Lau \& Sim, 2008; Russell, Bebell, O’Dwyer, \& O’Connor, 2003).

Furthermore, other research found no significant effect of teaching experience on teachers' readiness to implement technology (Alazzam, Bakar, Hamzah, \& Asimiran, 2012; Mueller, Wood, Willoughby, Ross, \& Specht, 2008). Singh and Chan (2007) conducted a study to investigate teacher readiness on ICT integration in teaching and learning in Malaysia. The study found that the attitudes of teachers to integrate technology vary with their years of experience. Teachers with less years of teaching experience showed higher levels of knowledge and more positive attitudes as their experience with technology increases. Likewise, Baek et al. (2008) reported that teachers with long teaching experience are less ready to integrate technology into their instruction. The results of the U.S. Department of Education, National Center for Education Statistics (2000) were consistent with these findings. The report declared that teachers with less teaching experience tend to integrate technology in their instruction more than teachers who have long teaching experience. However, a study conducted by Lau and Sim (2008) showed that older teachers in Malaysia are more likely to use technology in the 
Teachers' Readiness to Implement Digital Curriculum in Kuwaiti Schools

classrooms than the younger teachers. This result confirmed the results of an earlier study conducted by Russell et al. (2003) who found that although novice teachers had more knowledge and high skills in the use of technology, they integrate technology in their teaching less than older teachers do.

\section{Objectives}

This study investigates teachers' readiness for digital curriculum implementation in all grades within the school system in Kuwait. The study focuses on teachers' use of a variety of digital learning tools to implement the curriculum. Teachers' implementation of the digital curriculum can be done through the use of various digital tools, such as iPod touches, iPads, iMacs, Smart Boards, online learning assessment, and various Windows based computers. The study also focuses on investigating teachers' readiness and its relationship with some variables such as years of experience, the grade level they teach (elementary, intermediate, secondary) and their subject area. In particular, the research questions addressed in the study are as follows:

1. How do teachers perceive their own readiness to implement digital curriculum in Kuwaiti schools?

2. Are there relationships between teachers' readiness level to implement digital curriculum and their demographic characteristics?

3. What are the factors that affect teachers' readiness to implement digital curriculum in Kuwaiti schools from the teachers' perspectives?

\section{SIGNIFICANCE OF THE STUDY}

In spite of all the efforts that have been made by the Kuwaiti government to equip schools with the most advanced digital technologies, evidence suggests that information technology has not yet been integrated adequately into the curriculum in most Kuwaiti public schools. In order for this objective to be attainable, the teachers' readiness to use technology in their practice should be looked at as an important factor. This study seeks to investigate one of the key factors that affect teachers' readiness for digital curriculum implementation. The results of the study will be helpful for curriculum decision makers in the Ministry of Education in Kuwait to guide them to the best ways to implement digital curriculum and support teachers to implement the digital curriculum.

\section{METHODOLOGY}

Schooling in Kuwait starts at the age of six, and the educational system consists of three levels: elementary (lasts for 5 years), intermediate (lasts for 3 years), and secondary (lasts for 5 years). The study investigates the perspectives of public school teachers of their readiness to implement the digital curriculum across these grade levels. Teachers might be ready to implement the digital curriculum in one subject but not for others depending on the levels of their teaching experience. Furthermore, teachers might be ready to implement digital curriculum in a grade level but not for another grade level. Therefore, the two factors, grade levels (elementary, intermediate and secondary) and subject taught, will be considered in relation to teachers' readiness. The focus will be on the main subjects, (English, Arabic, Math, Science, and Social Studies).

In addition, the study focuses on two main aspects of readiness: pedagogical readiness and technical readiness. Pedagogical readiness in this study refers to the knowledge, skills, attitude, and habits of instructors to integrate technology appropriately in the curriculum. On the other hand, technical readiness has to do with teachers' knowledge and skills to implement the curriculum, availability of hardware and software for teachers and students, and types of professional development programs set by schools and the Ministry of Education to prepare teachers to implement the digital curriculum. 


\section{SAMPLE OF THE POPULATION}

The study's population included all teachers in public schools in Kuwait during the school year 2015/2016. All teachers in Al-Ahmadi school district were invited to participate in the study. AlAhmadi school district is one of six school districts in Kuwait. It was selected based on the size of its teacher population. The total teacher population is 2212 teachers (987 male and 1225 female teachers).

\section{DATA COLLECTION METHODS}

To collect data, the researchers used a combination of qualitative and quantitative approaches. To collect the quantitative data, the researchers developed a survey based on a review of related literature. Semi-structured interviews were implemented to gain a deep understanding of teachers' readiness and to identify the factors that affect their readiness level. Furthermore, the use of different tools allowed researchers to validate the results of the study, and hence obtain results that are more reliable.

\section{SURVEY}

Researchers developed a technology readiness survey intended to measure teachers' knowledge, attitudes, skills, and habits toward the implementation of the digital curriculum. The survey questionnaire includes description of the respondents' perceptions about their confidence to implement digital curriculum and the skills they already have to implement the digital curriculum. The researchers developed the survey items based on a review of the literature on technology readiness including Parasuraman's (2000) Technology Readiness Index (TRI) and Bonanno's (2011) readiness survey. The survey consisted of two sections. The first section was demographic information (gender, teaching experience, specialty, nationality, grade level). The second section consisted of 28 items that asked respondents to evaluate their technical and pedagogical readiness to implement digital curriculum. Sixteen items measured technical readiness and twelve items measured pedagogical readiness. Each item of the survey was measured on a common Likert scale, continuum of 1 to 5 with " 1 " representing "strongly disagree" and " 5 " representing "strongly agree". The survey was evaluated for face and content validity and reliability by an expert panel. The expert panel included expert teachers and three professors who are specialists in curriculum and instruction and educational technology at the College of Education at Kuwait University. Panel members were asked to provide feedback on the readability of items and the appropriateness of the items according to the objectives. They were also asked to suggest any addition or deletion of any items based on their knowledge.

Cronbach's Alpha was employed to measure the internal consistency of items in the survey. It was found to be 0.931 , which surpassed 0.9. Therefore, the reliability of the items was deemed to be excellent (George \& Mallery, 2003).

The researchers used an online anonymous survey created in Survey Monkey to collect quantitative data. The online survey was used because of ease of collection of responses and for preserving anonymity of the research participants (Sue \& Ritter, 2007). The link to the survey was sent to the schools principals after obtaining permission from the Ministry of Education. Then, the principals forwarded the survey link to the teachers. The survey link was available from 24th April to 1st June, 2016. While the link was online, the school principals sent reminders to teachers every week.

\section{INTERVIEW}

To gain a deep understanding of teachers' readiness and to identify the factors that affect their readiness level, semi-structured interviews were implemented. The main goal of an interview is to identify the feelings, opinions, beliefs, and perceptions of the participant in the research (Cohen \& Mannion, 1998; Yıldırım \& Simsek, 2005). 
Teachers' Readiness to Implement Digital Curriculum in Kuwaiti Schools

Initially, 53 teachers agreed to participate in the interviews; however, researchers were not able to interview all of them due to the difficulty to connect with some of them or difficulty to find a suitable time to carry out the interviews. Eventually, researchers were able to interview only 21 teachers. Participants in the interviews represented the three school levels (elementary, middle, and secondary schools), teachers with different levels of teaching experiences, and teachers specializing in art and science. Two graduate students assisted the researchers to conduct the interviews after receiving appropriate training from the researchers.

The semi-structured interviews were implemented to encourage teachers to make open-ended comments. The questions focused on the factors that affect teachers' readiness to implement the digital curriculum. In the interviews, the main question was "from your point of view, what are the factors that affect your integration of technology in curriculum?" Other questions followed some responses to provide a deeper understanding or to seek further clarification, such as "Could you explain more?", "What other factors can you mention?" "How do these factors affect you?" During each interview, respondents were motivated to elaborate their responses or to share information concerning the factors that affect their implementation of the digital curriculum.

\section{DESCRIPTION OF SURVEY PARTICIPANTS}

A total of 591 participants responded to the survey. Participants were asked in the survey if they are willing to participate in an interview regarding their readiness to implement digital curriculum. Only 53 teachers volunteered to participate in the interview. The sample included a broad spectrum of teachers across grade levels and subject areas of the teachers.

Out of 591 distributed surveys, 532 were selected for data analysis, and fifty-nine surveys were discarded. Some responses (34) were discarded due to straight lining response pattern, which indicates that respondents wanted to finish the survey quickly, rather than reading the questions and giving the answer some thought. The other responses (25) were discarded because they were completed by school administrators. A summary of the demographic characteristics of the sample is presented in Table 1.

\begin{tabular}{|c|c|c|}
\hline \multicolumn{3}{|l|}{ Table 1. Demographics of the participants } \\
\hline & $\mathrm{N}$ & $\%$ \\
\hline \multicolumn{3}{|l|}{ Gender } \\
\hline Male & 97 & 18.23 \\
\hline Female & 435 & 81.77 \\
\hline \multicolumn{3}{|l|}{ Nationality } \\
\hline Kuwaiti & 381 & 71.61 \\
\hline Non Kuwaiti & 151 & 28.39 \\
\hline \multicolumn{3}{|l|}{ Subject } \\
\hline Science & 313 & 58.84 \\
\hline Art & 219 & 41.16 \\
\hline \multicolumn{3}{|l|}{ Years of teaching experience } \\
\hline Less than 5 & 124 & 23.31 \\
\hline From 5 to 10 & 137 & 25.75 \\
\hline More than 10 and less than 15 & 109 & 20.49 \\
\hline More than 15 & 162 & 30.45 \\
\hline
\end{tabular}




\section{DATA ANALYSIS}

The survey data was analysed to answer the first two research questions. The data were analyzed using descriptive statistics (means, standard deviations, and percentiles) and multivariate analysis (MANOVA) to examine the differences. The levels of teachers' readiness were based on the mean scores of teachers' responses on the survey. The results of the average means were classified into three levels: 1.00 to 2.49 indicates low level of readiness, 2.50 to 3.49 indicates moderate level of readiness, and $3.50-5.00$ indicates high level of readiness.

To determine the factors that affect teachers' readiness to implement digital curriculum, semistructured interviews were used for data collection. Face to face, interviews were conducted between April and May 2016. All the interviews were conducted in the Arabic language. The interviews were audio-recorded and transcribed verbatim for the analysis. The researchers translated the transcriptions from Arabic to English. They cross-checked each other's transcripts to ensure the accuracy of the transcription, since Burns (2000) and Silverman (2000) emphasized that if two or more people have similar interpretations, the reliability of the interpretation can be enhanced.

The interview transcripts were analyzed for thematic content (Uzuntiryaki, 2008). To minimize biases and improve the quality and credibility of findings, the two researchers independently evaluated interview-data. The interview data were transcribed, coded, categorized, and evaluated to find emergent themes.

The researchers came to an agreement on 53 statements that were categorized into two major categories. The first category was related to the factors that encourage teachers to implement the digital curriculum, while the second category was related to the factors that hinder teachers' implementation of the digital curriculum. Under each category, several themes emerged indicating participants' perceptions about factors that affect their readiness to implement digital curriculum in their teaching.

Then, an inter-rater reliability analysis (Kappa statistic) was calculated to find the consistency between the raters. Results showed that there was a high degree of agreement, with Fleiss kappa being 0.91 among raters. A Kappa higher than 0.80 indicates good agreement (Pallant, 2007).

\section{FINDINGS}

\section{TEACHERS'PERCEPTIONS ABOUT THEIR OWN READINESS TO IMPLEMENT DIGITAL CURRICULUM IN KUWAITI SCHOOLS}

To answer the first research question, "How do teachers perceive their readiness to implement digital curriculum?", results of teachers' readiness were presented in two groups. The first group of items addressed teachers' technical readiness and the second group addressed pedagogical readiness items. The descriptive data and findings of the 16 items that represent teachers' perceptions on their technical readiness to implement the digital curriculum are reported in Table 2 . The mean scores of teachers' responses ranged from 2.51 to 4.33 and this range of mean indicates medium and high level of readiness.

Teachers exhibited a moderate level of technical readiness to implement the digital curriculum in most of the items ( 9 out of sixteen), high readiness level on the remainder ( 7 out of 16), and none of the items was at a low level of readiness. The mean score of the moderate readiness items was between 2.51 and 3.38. The lowest mean score was for items related to teachers' abilities to create wikis or web sites $(M=2.51, S D=1.19)$, familiarity with creating blogs $(M=2.70, S D=1.22)$, and ability to design online quizzes and use them in teaching $(M=2.70, S D=1.26)$.

The mean score for the high readiness items was between 3.72 and 4.33 . The highest two mean scores were on the items: "I take with me a mobile device connected to the internet everywhere I go" $(\mathrm{M}=4.33, \mathrm{SD}=1.18)$ and "I am competent in using presentation software such as PowerPoint." (M $=4.06, \mathrm{SD}=1.28$ ). 
Teachers' Readiness to Implement Digital Curriculum in Kuwaiti Schools

\begin{tabular}{|r|l|r|c|}
\hline \multicolumn{3}{|c|}{ Table 2. Means and standard deviations for the survey items teachers' technical readiness } \\
\hline & \multicolumn{1}{|c|}{ Survey Items } & Mean & SD \\
\hline 1. & I take with me a mobile device connected to the internet everywhere I go. & 4.33 & 1.18 \\
\hline 2. & I am competent in using e-mail. & 3.86 & 1.14 \\
\hline 3. & I am competent in using word processing software. & 3.99 & 1.25 \\
\hline 4. & I am able to download files from the Internet and upload files to the e-mail. & 3.72 & 1.35 \\
\hline 5. & I am competent in using presentation software such as PowerPoint. & 4.06 & 1.28 \\
\hline 6. & I am familiar with and can create a blog. & 2.70 & 1.22 \\
\hline 7. & I am familiar with and can create wikis or Web sites. & 2.51 & 1.19 \\
\hline 8. & I can use social media (Twitter, Instagram,...) to communicate with my students. & 3.75 & 1.38 \\
\hline 9. & I am familiar with learning management systems (Blackboard, ...). & 3.00 & 1.22 \\
\hline 10. & $\begin{array}{l}\text { I am able to convert the printed content and activities in the curriculum to the digital } \\
\text { form. }\end{array}$ & 3.75 & 1.19 \\
\hline 11. & I am able to design online quizzes and use them in teaching my classes. & 2.70 & 1.26 \\
\hline 12. & I am able to use online discussions and teaching my classes. & 2.85 & 1.26 \\
\hline 13. & I am able to use chat in teaching my classes. & 3.00 & 1.35 \\
\hline 14. & I am able to publish my lessons and classroom activities on the web. & 3.34 & 1.31 \\
\hline 15. & I am able to use learning management system to supplement my teaching. & 2.85 & 1.22 \\
\hline 16. & I can develop electronic learning activities that encourage my students to be critical \\
& thinkers. & 3.38 & 1.19 \\
\hline
\end{tabular}

\begin{tabular}{|c|c|c|c|}
\hline \multicolumn{4}{|c|}{$\begin{array}{c}\text { Table 3. Means and standard deviations for the survey items teachers' } \\
\text { pedagogical readiness }\end{array}$} \\
\hline & Survey Items & Mean & SD \\
\hline 1. & I can use technology to support my teaching methods. & 3.98 & 1.12 \\
\hline 2. & I am familiar with the ways of integrating technology into curriculum. & 3.11 & 1.36 \\
\hline 3. & I believe that digital curriculum is as rigorous as printed curriculum. & 3.41 & 1.32 \\
\hline 4. & $\begin{array}{l}\text { I believe that high quality learning experiences can occur without interacting with } \\
\text { students face-to-face. }\end{array}$ & 2.88 & 1.28 \\
\hline 5. & $\begin{array}{l}\text { I support the interaction among students and collaborative activity as a means of } \\
\text { teaching and learning. }\end{array}$ & 3.50 & 1.18 \\
\hline 6. & $\begin{array}{l}\text { I recognize that community building is an important component of digital curricu- } \\
\text { lum. }\end{array}$ & 3.60 & 1.11 \\
\hline 7. & $\begin{array}{l}\text { I encourage my students to bring life experiences into the classroom and create } \\
\text { activities based on those experiences. }\end{array}$ & 3.58 & 1.13 \\
\hline 8. & $\begin{array}{l}\text { I feel comfortable communicating online and feel that I am able to convey my mes- } \\
\text { sage writing. }\end{array}$ & 3.37 & 1.19 \\
\hline 9. & I am able to manage my time well in a technology-enriched classroom. & 3.60 & 1.16 \\
\hline 10. & $\begin{array}{l}\text { I am flexible in dealing with students on such issues as due dates, absences, and } \\
\text { makeup assignments. }\end{array}$ & 3.31 & 1.19 \\
\hline 11. & I am fairly organized and tend to plan ahead in my technology based teaching. & 3.64 & 1.18 \\
\hline 12. & I can manage and control students learning in a technology-enriched classroom. & 3.31 & 1.21 \\
\hline
\end{tabular}


The findings of the 12 items that represent teachers' perceptions on their pedagogical readiness to implement the digital curriculum are presented in Table 3. The mean scores for participant responses in all the pedagogical readiness items ranged from $2.88-3.98$. This indicates moderate and high level of readiness. Teachers indicated a moderate level of readiness in half of the items (6 out of 12), and the mean scores of the other half of the items were at the high level of teachers' readiness. None of the items was at the low level of readiness. The highest mean score was for the item "I can use technology to support my teaching methods" $(\mathrm{M}=3.98, \mathrm{SD}=1.12)$, while the lowest was for the item "I believe that high quality of learning experience can occur without interacting with students face-toface $(\mathrm{M}=2.88, \mathrm{SD}=1.28)$.

\section{RELATIONSHIPS BETWEEN TEACHERS'READINESS LEVEL TO IMPLEMENT DIGITAL CURRICULUM AND SOME OF THEIR DEMOGRAPHIC VARIABLES}

The second research question is "Are there relationships between teachers' readiness level to implement digital curriculum and their demographic characteristics?"

Table 4 illustrates variation in the means and standard deviations of teachers' technical and pedagogical readiness to implement digital curriculum. This variation is due to the variance of area of specialty, grade levels taught, and years of teaching experience.

It was observed that teachers who teach science subjects were more ready in both the technical and pedagogical dimensions of readiness to implement digital curriculum. It was also observed that the teachers of intermediate level students have higher technical and pedagogical readiness to implement digital curriculum than those who taught the other two levels (elementary and secondary). Secondary teachers showed more technical readiness than elementary teachers. On the other hand, elementary teachers showed higher levels of pedagogical readiness than secondary teachers did.

\begin{tabular}{|c|c|c|c|c|}
\hline & \multicolumn{2}{|c|}{ Technical } & \multicolumn{2}{|c|}{ Pedagogical } \\
\hline & $\mathrm{M}$ & $\mathrm{SD}$ & M & SD \\
\hline \multicolumn{5}{|l|}{ Area of specialty } \\
\hline Science $(\mathrm{n}=219)$ & 3.58 & .78 & 3.59 & .84 \\
\hline $\operatorname{Art}(\mathrm{n}=313)$ & 3.21 & .85 & 3.34 & .88 \\
\hline \multicolumn{5}{|l|}{ Grade Level } \\
\hline Elementary $(\mathrm{n}=157)$ & 3.29 & .88 & 3.4 & .91 \\
\hline Intermediate $(\mathrm{n}=180)$ & 3.46 & .81 & 3.53 & .85 \\
\hline Secondary & 3.32 & .83 & 3.35 & .87 \\
\hline \multicolumn{5}{|l|}{ Years of teaching experience } \\
\hline Less than 5 (123) & 3.47 & .66 & 3.57 & .72 \\
\hline from 5 to 10 (138) & 3.47 & .79 & 3.52 & .89 \\
\hline $\begin{array}{l}\text { more than } 10 \text { and less } \\
\text { than } 15(\mathrm{n}=109)\end{array}$ & 3.47 & .69 & 3.55 & .70 \\
\hline more than $15(\mathrm{n}=162)$ & 3.13 & 1.03 & 3.21 & 1.02 \\
\hline Total $(n=532)$ & 3.44 & .88 & 3.36 & .84 \\
\hline
\end{tabular}


Teachers' Readiness to Implement Digital Curriculum in Kuwaiti Schools

In order to understand the statistical significance of these differences, multivariate analysis of variance (MANOVA) was implemented for each domain and for the overall instrument as presented in Table 5.

\begin{tabular}{|c|c|c|c|c|c|c|}
\hline Source & $\begin{array}{l}\text { Dependent Vari- } \\
\text { able }\end{array}$ & $\begin{array}{c}\text { Type III Sum of } \\
\text { Squares }\end{array}$ & d.f. & Mean Square & $\mathrm{F}$ & Sig. \\
\hline \multirow{3}{*}{$\begin{array}{l}\text { Area of Spe- } \\
\text { cialty }\end{array}$} & Pedagogical & 8.50 & 1 & 8.50 & 11.89 & .001 \\
\hline & Technical & 17.04 & 1 & 17.04 & 26.49 & .000 \\
\hline & Total & 13.022 & 1 & 13.022 & 21.02 & .000 \\
\hline \multirow[t]{3}{*}{ Grade Level } & Pedagogical & 3.88 & 2 & 1.939 & 2.712 & .067 \\
\hline & Technical & 3.64 & 2 & 1.820 & 2.828 & .060 \\
\hline & Total & 3.478 & 2 & 1.739 & 2.805 & .061 \\
\hline \multirow[t]{3}{*}{ Experience } & Pedagogical & 12.977 & 3 & 4.326 & 6.049 & .000 \\
\hline & Technical & 12.772 & 3 & 4.257 & 6.618 & .000 \\
\hline & Total & 12.760 & 3 & 4.253 & 6.861 & .000 \\
\hline
\end{tabular}

The independent variables were area of specialty (science and art), grade levels (elementary, intermediate, and secondary), and years of teaching experience (less than 5, from 5 to 10, more than 10-and less than 15 and above 15 years).

The results of the MANOVA (Table 5) suggested that teachers overall readiness and their readiness in the two dimensions of readiness (technological and pedagogical) were significantly different by teachers' specialty (Wilks' Lambda $=.95, \mathrm{~F}(2,507)=14.48, \mathrm{p}<0.001)$. The results of the MANOVA analysis for beginning teachers (less than 5 years of experience), for teachers with some experience (from 5 - 10 years), for the experienced teachers (more than $10-15$ years), and for highly experienced teachers (more than 15 years of experience), revealed significant differences in the overall readiness and the two dimensions of readiness (Wilks' Lambda $=.96, \mathrm{~F}(6,1014)=3.71, \mathrm{p}<0.001)$. Grade level was found to be not significant (Wilks' Lambda $=0.98, \mathrm{~F}(4,1014)=2.62, \mathrm{p}=0.34)$.

To understand the differences in readiness between science and art teachers, the mean scores for both groups of teachers was inspected. It was found that the mean score for science teachers was higher than the mean score for art teachers in the two dimensions of readiness. Science teachers reported higher levels of technical readiness $(\mathrm{M}=3.58, \mathrm{SD}=.78)$ than art teachers did $(\mathrm{M}=3.21, \mathrm{SD}$ $=.85)$. Science teachers also reported higher levels of pedagogical readiness $(\mathrm{M}=3.59, \mathrm{SD}=.84)$ than art teachers did $(\mathrm{M}=3.34, \mathrm{SD}=.88)$.

Since the MANOVA tests indicated that there were statistically significant effects, a one-way withinsubject analysis of variance (ANOVA)'s on each subscale score was conducted as follow-up tests.

As shown in Table 6 for the teaching experience variable, the ANOVA results indicate that statistically significant differences were found in the pedagogical readiness $[\mathrm{F}(3.528)=5.83, \mathrm{p}<.001]$; technical readiness $(\mathrm{F}(3.528)=6.388, \mathrm{p}<.001]$ and the total readiness score $[\mathrm{F}(3.528)=6.639, \mathrm{p}=.000]$. 


\begin{tabular}{|l|l|c|c|c|c|c|c|c|}
\hline Table 6. The results on the follow-up ANOVA of teachers' readiness on both subscale scores \\
and years of experience \\
\hline
\end{tabular}

A Scheffe post hoc analysis of all sub-scales of teachers' readiness suggests that highly experienced teachers exhibit less readiness to implement the digital curriculum, overall and in both dimensions of readiness, than the less experienced teachers.

\section{FACTORS AFFECTING TEACHERS'READINESS TO IMPLEMENT DIGITAL CURRICULUM}

To determine the factors that affect teachers' readiness to implement digital curriculum, semistructured interviews were used for data collection. Face to face interviews were conducted with 21 teachers.

The results obtained from interviewees are presented under two major categories. The first category includes the factors that enhance teachers' readiness to implement the digital curriculum. The second category includes the factors that are considered barriers to implementing the digital curriculum and negatively affect teachers' readiness.

\section{Factors that enhance teachers' readiness to implement the digital curriculum}

Teachers reported three main factors that encourage them to implement digital curriculum. They believe that they are motivated to implement the digital curriculum because they believe that using digital technology can enhance students' performance (57\%), digital technology is an effective tool for teaching and learning (38\%), and digital technology can help teachers utilize innovative methods of teaching $(24 \%)$.

Enhancement of the students' performance: Teachers pointed out that integrating digital technology in students learning had a positive effect on their students' learning. The use of technology has increased students' involvement in classroom activities and helped them to be active participants in these activities. Twelve teachers (57\%) believe that implementing digital curriculum increases students' performance, "since I started using computers to present my lesson, my students have become more active and their achievements have increased." One teacher reported, "My students who are low achievers and rarely participate in classroom discussion, have become more active when using technology, they participate in classroom activities, answer questions and even ask questions and their achievements have significantly improved."

Perceived effectiveness of digital technology: Teachers believe that using digital technology can be very effective in enhancing the implementation of the curriculum (8 teachers). Integrating digital curriculum into the curriculum helps transform it to be more interactive. Teachers regard technology as an effective tool that can be used as an open source of information and a curriculum delivery tool. Teachers suggested many ways of utilizing technology within the curriculum. One teacher stated, "Technology provides me with a rich source of information and helps me collect information from a variety of learning materials". Another respondent added, "I refer to the internet all the time to get more resources for my lessons". When asked "why?" she replied, "I feel that the information in the text book is very limited and my students like to learn more, so I use YouTube to show them videos about the topic". An English teacher added, "I refer to the internet to access classroom activities like worksheets, songs, and online dictionary". Fourteen teachers reported that they refer to the internet 
to get worksheets, presentations, and videos. Nine teachers consider technology to be an effective tool to present lessons, "I can use Data show and PowerPoint presentations to deliver all my lessons and this helps me enhance the level of attention and comprehension among my students." One teacher reported that she uses the management system "Edmodo" to post her class materials, interact with students, and conduct online quizzes.

Innovative methods of teaching: As reported by teachers, digital technology has changed the way teachers teach. Five teachers reported that technology helps them to utilize innovative teaching methods that cannot be applied without technology. Three methods of teaching were reported: digital storytelling, online discussions, and collaborative learning.

Digital story telling is one of the factors that encourage teachers to use technology. Elementary teachers reported that using digital stories increases the engagement level of their students. For example, one elementary teacher stated, "Digital storytelling is a magical teaching strategy; when I use it with my students they quickly comprehend the new concepts and become highly motivated to learn more." Another added, "Students become more focused on learning and formulate questions, they even added more details to the stories".

Secondary and intermediate teachers were encouraged to use technology because technology permits them to implement innovative teaching methods. The first method as reported by four teachers was online discussions. Teachers reported that they use online discussions with their students. Two teachers indicated they use blogs to discuss some issues with their students, "my students enjoy these activities and they all participate in any topic I post for them."

Working in collaborative web based projects is another strategy reported by three teachers. Participants provided many examples of these projects, "I ask each group of my students to use google sites to design a web page about one of the topics in the curriculum". Another teacher asked her students to design videos and upload them to the YouTube, "In groups my students use Viv video application, to design video clips".

\section{Factors negatively affect teacher's readiness to implement the digital curriculum}

Participants reported many factors that negatively affect their readiness to implement the digital curriculum. These factors related to time constraints (85\%), lack of knowledge and skills $(71 \%)$, lack of infrastructure (62\%), and technical problem (57\%).

Time Constraints: The vast majority of the participants (18) reported time constraints as a major impediment affecting their perceived readiness to implement the digital curriculum. Teachers state time constraint as a factor that makes them reluctant to use technology in teaching. Participants complained that they do not have adequate time to integrate technology. They stated that they have a heavy teaching workload and do not have time to prepare computer based activities like presentations, worksheets, or interactive activities. Moreover, teachers do not have the flexibility to implement the curriculum. They have to follow the weekly plan and the teaching guidelines they received from the MoE every week. For example, one teacher stated, "I have to follow exactly what is in the textbook", she explained, "because the Ministry of Education provides us with a weekly plan and I have to follow this plan". Another teacher explained, "The Ministry of Education gives us a time limit to cover each unit and each subject in the curriculum, so the main priority is to cover all the content of the textbook regardless of how I cover it. There is time specified from the Ministry of Education for teaching each unit and for weekly exams".

Lack of knowledge and skills: Most teachers (15) stated that they have high technical skills in using technology for personal use, but they feel that they do not have the knowledge and skills to integrate technology in the curriculum. Teachers believe that appropriate training in the use of technology for education purposes is what they need. Teachers need to have training in order to be able to implement digital curriculum. The majority of the teachers indicted (18 out of 25$)$ that they have never attended any training in technology integration in the curriculum. Teachers who attended train- 
ing sessions ( 7 teachers) indicated that the training sessions focused on basic computer skills related to the use of Word processing, PowerPoint, Excel, and other applications.

It can be inferred from the data that the training held by the Ministry of Education is not effective. This training is focusing more on technical skills and technology itself rather than on teaching with technology. For example, one teacher reported, "I am very proficient in the use of technology for my personal purposes, but I cannot use it in the classroom". When they asked about their needs to improve their skills, they emphasized the need for training. "The most important thing I need is training. I have attended several training sessions, but they were useless". They explained, "In the training sessions they teach me about things I already know. What I really need is how to use technology to teach my class, build my lessons, design activities, and evaluate my students by technology". Another respondent added, "I have attended more than one training session on computer use, but I still feel unconfident to integrate technology in the curriculum."

Lack of infrastructure: Although technology is available in schools, most teachers indicated that it is not enough. Over half of the interviewees (13) addressed the lack of equipment in schools as a major factor that hinders their use of technology. Examples of interview responses are, "I have to bring my own computer or data show sometimes". Other teachers reported, "I cannot use any kind of technology in the classroom, there are no electrical outlets in the classrooms", "since there is no electricity connection in the classroom, I have never used technology in my teaching". Not having internet in the classrooms is another challenge for teachers. More than 15 interviewees complain that there is no internet connection or the connection is poor, "computer without internet is useless, and no internet connection in our classrooms". Five teachers said that they connect their smartphone with the data show in the classroom to present internet materials.

Technical problems: This problem is identified as one of the major factors that hinder teachers to use technology in teaching. Fifty seven percent of the interviewees reported that computers and other technological devices in the classrooms are not working properly, that they stop working suddenly during class, or they do not work at all. The most frequently reported technical problems are "machine hangs", "programs cannot be launched", and "machines fail to work". A number of participants felt depressed when they faced these problems. Examples of interview responses are, "I spent most of my class time to solve technical problems", "although computers are available they are poorly maintained", "before I start my technology based lesson, I stay tense until the program starts running", "I have always been frightened of a sudden technical problem with technology equipment."

A follow up question was asked of participants whether their schools provide them with technical support. They replied that technical support was very slow to resolve problems.

Technical problems not only interrupt class, but also lead to additional problems in the class. Participant said that some problems appear because of technical problems. Teachers expressed these problems as follows: one teacher stated, "While I am busy trying to solve the technical problems, students misbehave and I lose control of the class". Another teacher reported, "because of the technical problems, I decided not to use technology at school instead I give my students homework and ask them to use their technological devices at home".

\section{DISCUSSION}

The state of Kuwait is an ambitious country and is highly motivated to provide its people with high quality education. Therefore, the MoE in Kuwait emphasized the use of technology in schools and the need to equip teachers with all skills needed for technology integration in the curriculum. A huge budget has been allocated to developing education and providing schools with the most advanced technology.

However, providing resources will not guarantee a successful implementation of technology in education (Gulbahar, 2010). Teachers have an important role in technology integration, and they are 
Teachers' Readiness to Implement Digital Curriculum in Kuwaiti Schools

considered one of the critical factors that determine the success of any education innovation. Their attitudes, beliefs, perceptions, and behaviors toward technology play a significant role in their adoption of technology.

This study investigated teachers' readiness to implement the digital curriculum in Kuwait. Teacher readiness was measured in terms of pedagogical and technical dimensions. Generally, the results of this study demonstrate that teachers' readiness level was moderate. The second research question investigated the differences in readiness across different groups of teachers. The study explored whether there are significant differences in teachers' readiness to implement digital curriculum due to subjects taught, years of teaching experience, and grade level.

The findings revealed significant differences among teachers in their readiness to implement digital curriculum attributed to years of teaching experience. Results showed that highly experienced teachers showed less readiness to implement the digital curriculum than other groups of teachers. This finding is consistent with the findings of previous studies (Baek et al., 2008; Inan \& Lowther, 2009; Singh \& Chan, 2007). When years of experience in teaching increases, teachers' feelings of readiness to implement technology decreases. In contrast, other studies (Lau \& Sim, 2008; Russell et al., 2003) indicated that experienced teachers are more committed to implementing technology than novice teachers. It is the responsibility of educational policy makers in Kuwait to understand the reasons for the reluctance of experienced teachers to integrate technology.

Regarding the differences among teachers in their readiness across subjects taught, significant differences were found between teachers. Teachers who teach science subjects showed higher levels of readiness than teachers who teach art subjects. This result was in agreement with a recent study conducted by Howard et al. (2015) that revealed a significant correlation between teachers' readiness to integrate technology and their subject areas. Similarly, our results are inconsistent with the results of the studies conducted by Badri et al. (2014) and Summak et al. (2010). These two studies reported that teachers' readiness to integrate technology is not associated with the subject they teach.

In terms of the difference among teachers across grade levels in their readiness to implement digital curriculum, no significant differences were found. This result is consistent with the results of a study conducted in the UAE by Badri et al. (2014) that found no relationship between teachers' technology-readiness and the grade levels they teach. However, this result is not in agreement with other previous studies (Barron at el., 2003; Russell et al., 2004; Williams, 2015; Wozney et al., 2006) that reported elementary school teachers have a more positive attitude and integrate technology in their instruction more frequently than teachers in the other grade levels.

Through face to face interviews, teachers identified many factors that encourage the implementation of digital curriculum, such as their beliefs that technology enhances students' performance, the effectiveness of technology as an instructional tool, and the support available for teachers to implement innovative teaching methods. On the other hand, they reported some factors that hinder their integration of technology. These impediments can explain why teachers do not perceive their readiness for the digital curriculum implementation highly. The most common factor that hinders teachers' readiness is lack of time. Teachers have heavy workloads and limited time that restrict their ability to integrate technology into the curriculum. Lack of infrastructure, lack of knowledge and skills in using technology, and technical problems are other factors reported by teachers.

Along with providing schools with the most advanced technology, the MoE should focus on teachers. Researchers (Gray, Thomas, \& Lewis, 2010; Hermans, Tondeur, Van Braak, \& Valcke, 2008; Koehler \& Mishra, 2009) indicated that increasing the amount of technology in the classroom was not sufficient to change teachers' technology practices without a shift in the teachers' pedagogical practices. This study revealed that teachers in Kuwaiti schools face many barriers, such as a restricted curriculum and lack of training in using technology, making sure that the use of technology in practice aligned with their pedagogical practices. 


\section{CONCLUSIONS AND FUTURE RESEARCH}

The promise of reaching full implementation of digital curriculum will not become a reality without the teachers' full support and a positive perception of readiness. Teachers must have the technical and pedagogical skills to use technology and the willingness to integrate technology in their teaching (Gura \& Percy, 2005). Teachers' professional development programs should be designed to equip teachers with technical skills and pedagogical knowledge to implement the digital curriculum.

To enhance teachers' readiness to implement the digital curriculum, the Ministry of Education should give teachers more flexibility in planning their lessons and in implementing the curriculum. Teachers do not feel free in executing the curriculum. The implementation of the curriculum should be easy and flexible, without being bounded by rigid timetables. Moreover, schools management should allocate more time for teachers to prepare technology-based activities.

The findings indicate that teachers have the desire to obtain technological and pedagogical knowledge to be able to integrate digital technology effectively in the curriculum. The results underline the need for more efforts to be undertaken by the MoE in Kuwait to improve teachers' readiness to implement digital curriculum. Education stakeholders need to be convinced that teachers' readiness is essential to successful implementation of the digital curriculum. The MoE has invested heavily in technology in the last few years. However, professional development training for teachers in new technologies was limited (Alharbi, 2012). Teachers in Kuwait need intensive professional training in the pedagogical use of digital technology to facilitate its integration into the curriculum. The MoE should provide training that is more extensive for both pre-service and in-service teacher training programs in preparing teachers for digital curriculum implementation. Education decision makers in Kuwait should pay more attention to the needs of teachers and provide them with all kinds support not only technical support, but also provide them with incentives to incorporate technology in the curriculum. In addition, factors such as those reported in this study point out areas that should receive more attention.

Teachers in Kuwait need intensive training in the use of the digital technology to fully support the digital curriculum. The MoE needs to develop a comprehensive plan for preparing teachers to fully and effectively integrate technology in the curriculum. The preparation plan must help teachers gain confidence in their abilities to implement the digital curriculum. Teachers need ongoing in-service training on how to integrate technology into the curriculum. The MoE should work collaboratively with the College of Education at Kuwait University and other institutions to include the necessary skills that enable teachers to do so.

The existing research about the implications of the digital curriculum is very limited and this study can be a starting point for future research in other areas related to teachers' implications of the digital curriculum. The current study clarified some of the factors that influence teachers' readiness to implement the digital curriculum in the Kuwaiti public schools. Further research needs to be conducted to investigate other factors that may affect teachers' readiness. There is a need to study the effectiveness of teacher education programs in preparing students teachers to implement the digital curriculum. In addition, future research is essential to observe teachers when implementing the digital curriculum to find out how the implementation is being achieved. Furthermore, a new study is needed to investigate the role of education decision makers in the MOE and school administrators in facilitating the implementation of the digital curriculum.

\section{ACKNOWLEDGEMENT}

The researchers would like to thank Kuwait University Research Sector for sponsoring this research project under no. [TT02/15]. 
Teachers' Readiness to Implement Digital Curriculum in Kuwaiti Schools

\section{REFERENCES}

Abbey, E. (2009). The digital curriculum: A conceptual framework of technology integration for a 1:1 school. Johnston, IA: Heartland Area Education Agency 11. Retrieved June 12, 2016 from http://jenniferhigdon.wikispaces.com/file/view/The Digital Curriculum 31F3935ECBABA.pdf

Afshari, M., Ghavifekr, S., Siraj, S., \& Jing, D. (2013). Students' attitudes towards computer-assisted language learning. Behavioral Sciences, 103, 852-859.

Al Sharija, M. (2012). Innovative leadership by school principles: Embedding information communication and technology in Kuwaiti schools. Journal of International Education Research, 8(4), 425-434.

Al Sharija, M., \& Qablan, A. (2012). Leadership strategies for integration of ICT in Kuwait schools: Perceptions, practices and possibilities. Public Policy and Administration Research, 2(6), 18-28. Retrieved February 26, 2017, from http://www.iiste.org/Journals/index.php/PPAR/article/viewFile/3332/3377

Alazam, A., Bakar, A. R., Hamzah, R., \& Asimiran, S. (2012). Effects of demographic characteristics, educational background, and supporting factors on ICT readiness of technical and vocational teachers in Malaysia. International Education Studies, 5(6), 229-243. doi: 10.5539/ies.v5n6p229

Alharbi, G. (2012). Primary school teachers' perceptions regarding ICT usage and equipment in Kuwait. Journal of International Education Research (IIER), 8(1), 55-62.

Badri, M., Al Rashedi, A., Yang, G., Mohaidat, J., \& Al Hammadi, A. (2014). Technology readiness of school teachers: An empirical study of measurement and segmentation. Journal of Information Technology Education: Research, 13, 257-275. Retrieved August 25, 2016 from https://www.informingscience.org/Publications/2082

Baek, Y. G., Jong, J., \& Kim, B. (2008). What makes teachers use of technology in the classroom? Exploring the factors affecting facilitation of technology with a Korean sample. Computers and Education, 50(8), 224-234.

Balanskat, A., Blamire, R., \& Kefalla, S. (2007). The ICT impact report: A review of studies of ICT impact on schools in Europe. European Schoolnet and European Commission. Retrieved May 29, 2016, from http://unpan1.un.org/intradoc/groups/public/documents/unpan/unpan037334.pdf

Barron, A. E., Kemker, K., Harmes, C., \& Kalaydjian, K. (2003). Large-scale research study on technology in k12 schools: Technology integration as it relates to the national technology standards. Journal of Research on Tecbnology in Education, 35(4), 489-507.

Bebell, I. D., Russell, M., \& O’Dwyer, L. M. (2004). Measuring teachers' technology uses: Why multiplemeasures are more revealing. Journal of Research on Technology in Education, 37(1), 45-63.

Becker, H., \& Anderson, R. (2001). School investments in instructional technology. Irvine, CA: Center for Research on Information Technology and Organizations.

Bonanno, P. (2011). Developing an instrument to assess teachers' readiness for technology-enhanced learning. $14^{\text {th }}$ International Conference on Interactive Computer Aided Learning (ICL2011), Piešt'any, Slovakia. 21-23 September, pp. 438-443

Buabeng-Andoh, C. (2012). An exploration of teachers' skills, perceptions and practices of ICT in teaching and learning in the Ghanaian second cycle schools. Contemporary Educational Technology, 3(1), 36-49.

Burns, R. B. (2000). Introduction to research methods (4th ed.). Melbourne, Australia: Longman.

Cohen, L., \& Mannion, L. (1998). Research methods in education. Bask1, London: Routledge Pres.

Cuban, L. (2001). So much high-tech money invested, so little use and change in practice: How come? Presented at the Council of Chief State School Officers' Annual Technology Leadership Conference. Washington, DC.

Du Plessis, A., \& Webb, P. (2012). Teachers' perceptions about their own and their schools' readiness for computer implementation: A South African case study. Turkish Online Journal of Educational Tecbnology - TOJET, 11(3), 312-325. 
Eady, M. J., \& Lockyer, L. (2013). Tools for learning: technology and teaching strategies. In Learning to teach in the primary school, Queensland University of Technology, p. 71. Retrieved May 17, 2016, from http:/ / ro.uow.edu.au/cgi/viewcontent.cgi?article $=1413 \&$ context=asdpapers

Ertmer, P. A., Ottenbreit-Leftwich, A. T., Sadik, O., Sendurur, E., \& Sendurur, P. (2012). Teacher beliefs and technology integration practices: A critical relationship. Computers and Education, 59(2), 423-435.

Eslaminejad, T, Masood, M, \& Ngah, N. A. (2010). Assessment of instructors' readiness for implementing elearning in continuing medical education in Iran. Medical Teacher, 32(10), e407-e412.

George, D., \& Mallery, P. (2003). SPSS for Windows step by step: A simple guide and reference. 11.0 update (4th ed.). Boston: Allyn \& Bacon.

Gray, L., Thomas, M., \& Lewis, L. (2010). Teachers' use of educational technology in US public schools: 2009 (NCES 2010-040). Washington, DC: National Center for Education Statistics, Institute for Education Sciences, U.S. Department of Education. Retrieved April 12, 2016 from http://nces.ed.gov/pubs2010/2010040.pdf

Gülbahar, Y. (2007). Technology planning: A roadmap to successful technology integration in schools. Computers \& Education, 49(4), 943-956.

Gura, M., \& Percy, B. (2005). Recapturing technology for education: Keeping tomorrow in today's classrooms, Lanham, Maryland: Scarecrow Education.

Hennessy, S., Ruthven, K., \& Brindley, S. (2005). Teacher perspectives on integrating ICT into subject teaching: commitments, constrains, caution, and change. Journal of Curriculum Studies, 37(2), 155-192.

Hermans, R., Tondeur, J., van Braak, J., \& Valcke, M. (2008). The impact of primary school teachers' educational beliefs on classroom use of computers. Computers \& Education, 51(4), 1499-1509.

Howard, S. K., Chan, A., \& Caputi, P. (2015). More than beliefs: Subject areas and teachers' integration of laptops in secondary teaching. British Journal of Educational Technology, 46(2), 360-369.

Inan, F. A., \& Lowther, D. L. (2009). Factors affecting technology integration in K-12 classrooms: A path model. Educational Technology Research and Development, 58(2), 137-154. doi:10.1007/s11423-009-9132-y

Kalogiannakis, M. (2008). Training with ICT for ICT from the trainee's perspective. A local ICT teacher training experience. Education and Information Technologies Journal, 15(1), 3-17. Retrieved from http://dx.doi.org/10.1007/s10639-008-9079-3

Koehler, M., \& Mishra, P. (2009). What is technological pedagogical content knowledge (TPACK)? Contemporary Issues in Technology and Teacher Education, 9(1), 60-70.

Koo, A. C. (2008). Factors affecting teachers' perceived readiness for online collaborative learning: A case study in Malaysia. Educational Technology \& Society, 11(1), 266-278.

Lau, B. T., \& Sim, C. H. (2008). Exploring the extent of ICT adoption among secondary school teachers in Malaysia. International Journal of Computing and ICT Research, 2(2), 19-36.

Law, N., \& Chow, A. (2008). Teacher characteristics, contextual factors, and how these affect the pedagogical use of ICT. In N. Law, W. J. Pelgrum \& T. Plomp (Eds.), Pedagogy and ICT use in schools around the world. Findings from the IEA SITES 2006 Study. CERC Studies in Comparative Education series, Vol. 23, pp. 181-219. Hong Kong: CERC-Springer.

Lim, C. P., Chai, C. S., \& Churchill, D. (2011). A framework for developing pre-service teachers' competencies in using technologies to enhance teaching and learning. Educational Media International, 48(2), 69-83. doi:10.1080/09523987.2011.576512

Martin, B. (2015). Successful implementation of TPACK in teacher preparation programs. International Journal on Integrating Technology in Education (IJTE), 4(1), 17-26.

Ministry of Education. (2003). General education strategy in the state of Kuwait 2005-2025. Kuwait Ministry of Education.

Ministry of Education. (2015). Kuwait national curriculum: A Guide for Effective Teaching of the English Language in Grade One: Guidelines for putting into practice the new Curriculum and Standards for English in Grade 1. Annual report. Kuwait government press. 
Teachers' Readiness to Implement Digital Curriculum in Kuwaiti Schools

Moeller, B., \& Reitzes, T. (2011). Integrating technology with student-centered learning. Quincy, MA: Education Development Center, Inc. Nellie Mae Education Foundation.

Mohammad, T. (2014). E-learning strategy in Ministry of Education in Kuwait. International Journal of Advanced Science and Engineering Technology, 4(1), 366-372.

Msila, V. (2015). Teacher readiness and information and communications technology (ICT) use in classrooms: A South African Case Study. Creative Education, 6, 1973-1981. Retrieved from http://dx.doi.org/10.4236/ce.2015.618202

Mueller, J., Wood, E., Willoughby, T., Ross, C., \& Specht, J. (2008). Identifying discriminating variables between teachers who fully integrate computers and teachers with limited integration. Computers \& Education, 51(4), 1523-1537.

$\mathrm{Ng}$, W. (2011). Mobile technologies and handheld devices for ubiquitous learning: research and pedagogy. Information Science Reference.

Pallant, J. (2007). The SPSS survival manual. Maidenhead, UK: OUP

Parasuraman, A. (2000). Technology Readiness Index (TRI). A multiple-item scale to measure readiness to embrace new technologies. Journal of Service Research, 2(4), 307-320.

Player-Koro, C. (2012). Factors influencing teachers use of ICT in education. Education Inquiry, 3(1), 93-108.

Purcell, K., Buchanan, J., \& Friedrich, L. (2013). The impact of digital tools on student writing and how writing is tanght in schools. Retrieved June 16, 2016 from http://www.pewinternet.org/files/oldmedia/Files/Reports/2013/PIP NWP\%20Writing\%20and\%20Tech.pdf

Ruggiero, D., \& Mong, C. J. (2015). The teacher technology integration experience: Practice and reflection in the classroom. Journal of Information Technology Education Research, 14, 161-178. Retrieved May 14, 2016 from http://www.informingscience.org/Publications/2227

Russell, D., Bebell, M., \& O’Dwyer, L. (2004). Measuring teachers' technology use: Why multiple measures are more revealing. Journal of Research on Technology in Education, 37(1), 45-63.

Russell, M., Bebell, D., O’Dwyer, L., \& O’Connor, K. (2003). Examining teacher technology use: Implications for preservice and inservice teacher preparation. Journal of Teacher Education, 54(4), 297-310.

Sabzian, F. \& Gilakjani, A. P. (2013). Teachers' attitudes about computer technology training, professional development, integration, experience, anxiety and literacy in English language teaching and learning. International Journal of Applied Science and Technology, 3(1), 67-75.

Sessoms, D. (2008). Interactive instruction: Creating interactive learning environments through tomorrow's teachers. International Journal of Technology in Teaching and Learning, 4(2), 86-96.

Sherry, L., \& Gibson, D. (2002). The path to teacher leadership in educational technology. Contemporary Issues in Technology and Teacher Education, 2(2), 178-203. Norfolk, VA: Association for the Advancement of Computing in Education (AACE).

Silverman, D. (2000). Doing qualitative research: A practical guide. Thousand Oaks, CA: Sage.

Silvernail, D. L., \& Gritter, A. K. (2007). Maine's middle school laptop program: Creating better writers. Center for Educational Policy, Applied Research, and Evaluation. Retrieved December 2, 2015, from http://maine.gov/mlti/resources/Impact on Student Writing Brief.pdf

Singh, T. K. R., \& Chan, S. (2014). Teacher readiness on ICT integration in teaching-learning: A Malaysian case study. International Journal of Asian Social Science, 4, 874-885.

Smaldino, S. E., Lowther, D. L., \& Russell, J. D. (2008). Instructional technology and media for learning (9th ed.). Columbus, OH: Pearson.

Sue, V. M., \& Ritter, L. A. (2007). Conducting online surveys. Thousand Oaks, CA: Sage Publications.

Summak, M., Baglibel, M., \& Samancioglu, M. (2010). Technology readiness of primary school teachers: A case study in Turkey. Procedia Social and Behavioral Sciences, 2, 2671-2675. 
Tatnall, A., Kereteletswe, O.C. \& Visscher, A. (2011) Information technology and managing quality education. 9th IFIP WG 3.7 Conference on Information Technology in Educational Management, ITEM (2010). Springer.

United States Department of Education, National Center for Education Statistics. (2000). Teachers' tools for the 21 st century. A report on teachers' use of technology. Washington, DC. Retrieved August 22, 2016, from https://nces.ed.gov/pubs2000/2000102.pdf

Uzuntiryaki, E. (2008). Exploring the sources of Turkish preservice chemistry teachers' chemistry self-efficacy beliefs. Australian Journal of Teacher Education, 33(6), 12-28.

UNESCO. (2011). World data on education: Kuwait (7th ed.). Geneva, Switzerland: International Bureau of Education. Retrieved November 22, 2015, from http://www.ibe.unesco.org/fileadmin/user upload/Publications/WDE/2010/pdfversions/Kuwait.pdf

Webb, M., \& Cox, M. (2004). A review of pedagogy related to information and communications technology. Technology, Pedagogy and Education, 13(3), 235-286.

Williams, C. (2015). An investigation of K-12 teachers' attitudes toward computer technology use in schools. Journal of Business \& Economic Policy, 2(1), 71-87.

Williamson, A., \& Payton, S. (2009). Curriculum and teaching innovation transforming classroom practice and personalization. A future lab bandbook. National Foundation for Educational Research. Retrieved Mach 10, 2016, from, http://archive.futurelab.org.uk/resources/documents/handbooks/curriculum and teaching innovation2. pdf

Wozney, L., Venkatesh, V., \& Abrami, P. C. (2006). Integrating computer technologies: Teachers' perceptions and practices. Journal of Technology and Teacher Education, 14(1), 173-207.

Yildirim, A., \& Simsek, H. (2005). Qualitative research methods in social sciences (5th ed.). Ankara: Seckin Publications.

Zucker, A. A., \& Hug, S. T. (2007). A study of the 1:1 laptop program at the Denver School of Science \& Technology. Denver, CO: Denver School of Science \& Technology. Retrieved February 25, 2017, from http://www.scienceandtech.org/documents/Technology/DSST Laptop Study Report.pdf

\section{BIOGRAPHIES}

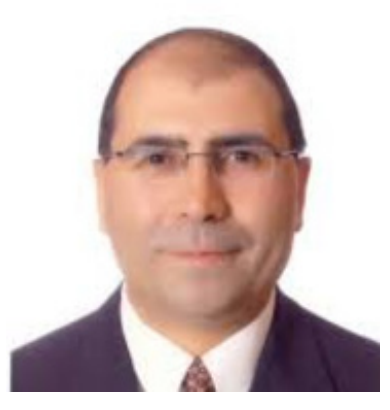

Dr. Hamed Mubarak Al-Awidi is a professor of curriculum and Instructional Technology, Kuwait University. He earned his $\mathrm{PhD}$ from the University of North Texas, U.S.A. Dr. Al-Awidi served as the chair of the training and development department at Yarmouk University in Jordan. His previous and ongoing research has focused on technology integration in elementary school setting, Innovations in Educational technology, Young Children and Computer, and application of new technology in Education. He teaches courses at both graduate and undergraduate levels including educational technology, computer education, children's' computerized programs and games, Advanced Study in curriculum and instruction, as well as many other courses. He has worked in different universities: UAE University, Yarmouk University- Jordan, and Currently Kuwait University. He is author or co-author on more than 30 peer reviewed publications. 


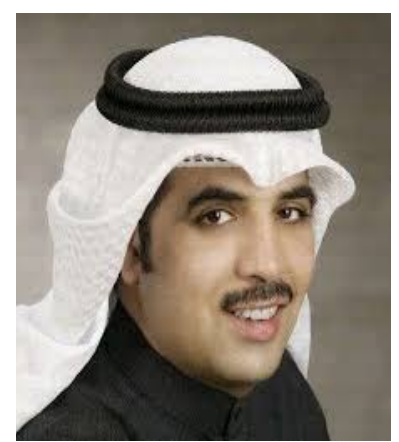

Fayiz Mensher Aldhafeeri is a professor in education technology at Kuwait University. He was the director of the Education Technology Center at Kuwait University. Professor Aldhafeeri received a distinguished teaching award from Kuwait University in 2004, presented by the Crown Prince of the State of Kuwait. He has published several research studies and reports in the area of e-learning and educational technologies in education and training and authored many books in the field of educational technology, including Computer Applications in Education, Educational Technology. He has presented at several international, regional, and local conferences. He has also designed and conducted more than 100 training, consultation, and supervision programs for various educational and corporate institutions inside and outside Kuwait in the following areas: courseware design/instructional design, presentation skills, training program evaluation techniques, training program delivery techniques, needs assessment techniques, training analysis techniques, successful and effective training, leadership skills, and educational communication and technology. 